\title{
Ny struktur i \\ Udenrigsministeriet
}

\section{Lars Bo Møller E \\ Rasmus Abildgaard Kristensen}

Udenrigsministeriet er blevet reorganiseret. Fremover overgår ministeriet fra sin nuværende opdeling i Nord og Syd til en struktur baseret på 11 centre. Formålet er at sikre en mere tidssvarende opgavefordeling, der tager højde for de nye udfordringer, som globaliseringen har sat skabt

Udenrigsministeriet skal have ny struktur. Der er tale om den mest gennemgribende reorganisering af Udenrigsministeriet siden 1991, hvor strukturen blev tilpasset den udenrigspolitiske virkelig efter den kolde krig. Organisationsændringerne er samtidig kulminationen på en omfattende fornyelses- og forandringsproces, som Udenrigsministeriet igangsatte i 2005 med henblik på at ruste ministeriet til at håndtere globaliseringens udfordringer.

Hvad er baggrunden for reorganiseringen? Hvori består ændringerne? På hvilke områder bryder den ny struktur med den eksisterende orga- nisation? Det er nogle af de spørgsmål, som vil blive belyst i denne artikel.

Artiklen falder i fire dele. Først beskrives Udenrigsministeriets globaliseringsproces og baggrunden for reorganiseringen. Dernæst redegøres for grundprincipperne i den ny struktur og indholdet af de øvrige organisationsændringer. Herefter undersøges, hvorvidt der er tale om brud eller kontinuitet, når der sammenlignes med den hidtidige struktur og den historiske udvikling i ministeriets organisation. Afslutningsvist diskuteres de udfordringer, som den ny organisation står overfor. 


\section{Globaliseringsprocessen}

Globaliseringen er det afgørende rammevilkår for Danmark og for varetagelsen af danske interesser internationalt i det 21. århundrede. Globaliseringen stiller dermed også nye krav til Udenrigsministeriet. Der er på mange måder tale om et paradigmeskift for ministeriets arbejde, som Murens fald og medlemskabet af EF også var det.

Med udarbejdelsen af Udenrigsministeriets Globaliseringsanalyse i 2006 igangsattes en proces, som skulle ruste ministeriet til at håndtere globaliseringens udfordringer og muligheder. Formålet med globaliseringsanalysen var at komme med konkrete og offensive bud på, hvordan Udenrigsministeriet bedst kunne bidrage til regeringens globaliseringsstrategi.

Globaliseringsanalysen indeholdt samtidig en analyse af de udfordringer og muligheder, som den internationale udvikling stiller Danmark og dermed Udenrigsministeriet overfor. Hovedtendenserne kan kort opsummeres således: For det første er der tale om en verden med langt mere komplekse udenrigspolitiske problemstillinger og med en række meget forskelligartede magtcentre. For det andet stiger betydningen af særligt ikkestatslige aktører, der har direkte indflydelse på udenrigspolitikken. Det gælder bl.a. terrororganisationer, religiøse grupper, NGO'er, virk- somheder og banker mv. Globaliseringen mindsker også skillelinjen mellem udenrigs- og indenrigspolitik. En indenrigspolitisk dagsorden kan lynhurtigt blive en global dagsorden, som sagen om Jyllandspostens tegninger demonstrerede. Samtidig udformes nationale politikker mere og mere i lyset af internationale aftaler og betingelser.

Danmark befinder sig også i en sikkerhedsmæssigt anderledes situation end i begyndelsen af halvfemserne. Det er en sikkerhedspolitisk situation, hvor der er en større trussel mod Danmark fra skrøbelige stater og terrororganisationer end fra supermagter med kernevåben.

Globaliseringen har endelig sat en række politiske temaer på dagsordenen, som ikke tidligere ville have været udenrigspolitisk stof. Det gælder klima og energi, migration, fødevarekrisen, finanskrisen samt værdipolitiske emner. Og ofte med en hastighed og en uforudsigelighed, som stiller krav om hurtig reaktion.

Disse nye internationale udfordringer er, som finanskrisen tydeligt har vist, ofte af et omfang og en kompleksitet som gør, at selv de største lande i verden ikke kan håndtere dem alene; men i et styrket multilateralt samarbejde.

Det har i debatten være fremført, at Udenrigsministeriets betydning og relevans mindskes under de nye rammebetingelser i takt med at andre danske aktører i stigende 
grad arbejder internationalt. Globaliseringsanalysen konkluderede imidlertid, at Udenrigsministeriet tværtimod har en afgørende og stadig vigtigere rolle at spille i forhold til disse ændrede rammebetingelser. Med sin adgang til såvel formelle internationale organisationer som uformelle internationale netværksdannelser. Som brobygger mellem danske interesser og aktører i udlandet. Og med en tværgående rolle i forhold til hjemlige spørgsmål med internationale aspekter ikke mindst i forhold til EU, men også i forhold til en lang række andre emner og aktører.

Men hvis Udenrigsministeriet skal indtage en central rolle og medvirke til at sikre maksimal dansk interessevaretagelse på den internationale scene, er der behov for, at ministeriet nytænker sin indsats og udvikler nye instrumenter og kompetencer. Det var baggrunden for udarbejdelsen af Globaliseringsanalysen.

Analysen opstillede konkret tre strategiske målsætninger, som skulle sætte ministeriet i stand til at handle effektivt i en globaliseret verden såvel ude som hjemme og i tæt samspil med andre danske myndigheder og aktører:

Udenrigsministeriet skal for det første stille skarpt på globaliseringens udfordringer. Det drejer sig bl.a. om international terrorisme, menneskerettigheder, den globale indsats mod fattigdom, post-konfliktløsning, globale miljø- og sundheds- spørgsmål, konkurrencen om internationale investeringer og eksport, men også øget migration samt kulturelle og religiøse strømninger.

Udenrigsministeriet skal for det andet skabe åbne og stærke partnerskaber. Efterhånden som der opbygges et globalt netværkssamfund, kan Danmark ikke længere sætte sin lid alene til de eksisterende mellemstatslige organisationer eller de traditionelle diplomatiske indflydelseskanaler.

Udenrigsministeriet skal derfor i endnu højere grad ud og være del af de uformelle netværk, herunder have kontakter til NGO'er og religiøse ledere.

Udenrigsministeriet skal endelig være til stede i globaliseringens økonomiske, politiske og sociokulturelle brændpunkter. Brændpunkterne er ikke konstante, men udvikler og flytter sig løbende, hvilket stiller krav om fleksibilitet og tilpasningsdygtighed fra ministeriets side.

Med Globaliseringsanalysen fra 2006 blev der skabt en tidssvarende strategisk ramme for Udenrigsministeriet, og der gennemførtes som opfølgning på analysen en række initiativer, som har bidraget til at skabe et endnu bedre og mere globaliseringsparat ministerium. Det gælder bl.a. etablering af et 24/7Borgerservicecenter, oprettelse af nye ambassader i en række af globaliseringens brændpunkter, opprioritering af Public Diplomacy-området samt styrket fokus på terror- 
bekæmpelse, skrøbelige stater, klima og miljø samt globale udviklingsspørgsmål.

\section{Behovet for en ny struktur}

I 2008 nedsattes en intern arbejdsgruppe med det formål at tænke videre ad Globaliserings-analysens spor og give sit bud på, hvordan Udenrigsministeriet kunne fortsætte tilpasningen til de nye rammebetingelser.

Hovedspørgsmålet var, om Udenrigsministeriets organisation i tilstrækkelig grad understøttede de nye strategiske målsætninger. Globaliseringsanalysen tog hul på dette emne med en række tværgående organisatoriske ændringer, som dog ikke udgjorde en egentlig reform af grundprincipperne for ministeriets organisation.

Udenrigsministeriets nuværende struktur og opgavefordeling har ikke ændret sig grundlæggende siden reorganiseringen efter murens fald. Dengang blev Udenrigsministeriet opdelt i to 'søjler' i form af en Nordgruppe, der skulle tage sig af alle sager vedr. EF, sikkerhedspolitik og de bilaterale relationer til lande i den industrialiserede verden. Samt en Sydgruppe med ansvar for de bilaterale relationer til resten af verden samt for udviklingsbistanden og politikken i FN og dens særorganisationer. Hertil kom en administrativ søjle. Siden etableredes i 2000 Danmarks Eksportråd.
Så hvilke krav stiller globaliseringen til Udenrigsministeriets organisation og struktur?

For det første er der behov for en mere tidssvarende opgavefordeling, således at der skabes en bedre forankring af særligt de nye emner såsom klima, terror og stabiliseringsindsatser, som ofte har skullet håndteres $\mathrm{i}$ ad hoc etablerede task forces. Samtidig bør der etableres en struktur og en opgavefordeling, som er lettere at forstå og samarbejde med for Udenrigsministeriets eksterne interessenter og samarbejdspartnere.

Globaliseringens kompleksitet betyder også, at Udenrigsministeriet til stadighed skal have kapaciteten til tidligt at forudse og analysere nye tendenser og politiske strømninger, hvis Danmark skal opnå indflydelse på eller præge den globale udvikling. I en omskiftelig verden har Udenrigsministeriet samtidig brug for en fleksibel og tilpasningsdygtig organisation for at kunne varetage de nye opgaver effektivt og fokuseret.

Endelig er der behov for at fremme enhedstjenesten, som er Udenrigsministeriets styrke. Det danske udenrigsministerium er unikt i den forstand, at det samler hele paletten af internationale opgaver, herunder udenrigs- og sikkerhedspolitik, udviklingsbistand og eksport- og investeringsfremme i én sammenhængende struktur, omfattende både hjemmetjenesten og udetjenesten. 
Enhedstjenesten gør det muligt at levere effektive svar på de globale udfordringer på tværs af arbejdsområder. Det kræver dog, at organisationen bliver endnu bedre til at samtænke indsatserne og udnytte de synergier, der ligger i enhedstjenesten, herunder i første række med en fælles tværgående koncernledelse.

\section{Den ny organisation}

Som opfølgning på arbejdsgruppens anbefalinger og med udgangspunkt i ovenstående hensyn besluttede udenrigsministeren, udviklingsministeren og den departementale ledelse ved årsskiftet 2008/2009 at indføre en ny struktur i Udenrigsministeriet.

Kernen i reorganiseringen er et endegyldigt opgør med reminiscenserne fra den horisontalt organiserede departementale struktur ved ophævelse af den nuværende opdeling i Nord og Syd til en struktur baseret på elleve centre i en funktionelt/geografisk afdelingsstruktur.

Som en direkte konsekvens af behovet for at styrke ministeriets tværgående indsats i forhold til terrorismebekæmpelse og udfordringen fra skrøbelige stater, herunder særligt Afghanistan, etableres et Center for Global Sikkerhed.

Formålet er at styrke håndteringen af de nye former for udviklingsbistand, der er langt mere politiske og typisk gennemføres under meget vanskelige omstændigheder i f $\mathrm{x}$ post-konfliktsituationer, og som kræver andre typer eksperter. Centret giver således mulighed for at kombinere sikkerhedspolitiske eksperter, specialister i humanitær bistand, militær- og politirådgivere samt civile eksperter med særlig erfaring fra post-konflikt situationer.

Der etableres også et Center for Globale Udfordringer, som skal fokusere på de nye prioriterede emner i krydsfeltet mellem udenrigspolitik og udviklingsbistand, herunder klima og energi, miljø, sundhed, fødevarekrisen, ligestilling, MDG3, menneskerettigheder og demokrati samt globale økonomiske spørgsmål. Ved at samle disse emner i ét center skabes en mere sammenhængende tilgang.

Fælles for alle disse problemstillinger er, at de kræver globale og multilaterale løsninger i regi af bl.a. FN og EU. Derfor vil de største multilaterale organisationer, herunder Verdensbanken, IMF og OECD, blive samlet i centret for at styrke Danmarks multilaterale indsatser.

En række af Udenrigsministeriets traditionelle kerneopgaver er blevet endnu vigtigere de senere år. Det gælder bl.a. EU-politikken, eksportfremmeindsatsen og den klassiske udviklingsbistand. Derfor oprettes et nyt Europacenter, som samler alle spørgsmål relateret til EU-samarbejdet, herunder de aktuelle og potentielle EU-ansøgerlande. For- 
målet er at styrke det faglige miljø omkring EU-politikken og styrke betjeningen af ministeriets danske samarbejdspartnere i EU-sager.

Endvidere oprettes et Center for Danmarks Eksportråd. Herved fortsættes professionaliseringen af det kommercielle arbejde. Centret forankrer ministeriets viden og kompetencer på det kommercielle område og udgør en synlig indgang for dansk erhvervsliv.

Et Center for Udviklingspolitik skal understøtte den markante danske udviklingspolitiske profil. Centret vil i endnu højere grad end i dag samle ekspertressourcerne på bistandsområdet og vil desuden have et tværgående ansvar og dermed sikre en fortsat sammenhængende kvalitetssikring af bistanden.

Der etableres også et Center for Koncern-HR og Ressourcer, som samler alle de funktioner, der arbejder strategisk med ministeriets økonomiske og menneskelige ressourcer. Formålet er at opprioritere ministeriets strategiske arbejde med HR samt økonomi og ressourcer.

Der lægges således op til en nyorientering af tilgangen til ministeriets personaleudvikling med henblik på at styrke ministeriets håndtering og udvikling af menneskelige ressourcer til gavn for både opgavevaretagelsen og alle medarbejdergrupper. Der vil i den forbindelse blive gjort en særlig indsats for at sikre, at Udenrigsministeriet også i fremtiden vil kunne bemande de vanskelige poster i udetjenesten, som der med den skærpede sikkerhedssituation er kommet flere af de senere år, samtidig med at den centrale økonomistyring fastholdes.

Ud over ovennæunte centre etableres yderligere fem centre, som i høj grad er en videreførelse af eksisterende enheder. Det gælder Borgerservice, Juridisk Tjeneste og Public Diplomacy. Endvidere etableres et center for landene i Afrika, Asien, Nord- og Sydamerika og Mellemøsten, der samler en række ensartede opgaver og står for den generelle håndtering af de bilaterale forhold.

Endelig etableres et selvstændigt center for Sikkerhed, Drift og Digitalisering, som dels samler ministeriets driftsopgaver, dels sættes fokus på sikkerhedsarbejdet i lyset af det nye trusselsbillede.

Ud over centrene etableres som noget helt nyt en planlægningsenhed tilknyttet ledelsen, som vil få til opgave at tænke frem og sikre, at organisationen hele tiden har fokus på de nye udviklingstræk og forholder sig strategisk til de nye udfordringer.

Udenrigsministeriets direktion vil fremover bestå af fem medlemmer: En departementschef, idet den arkaiske direktørtitel afskaffes til fordel for departementschefstitlen på linje med alle andre ministerier; en direktør for udenrigspolitiske emner; en direktør for udviklingspolitiske emner; en direktør for 
Danmarks eksportråd og administration; samt en politisk og strategisk direktør, der har ansvaret for strategiudvikling.

Det daglige operationelle ansvar for de løbende sager ligger hos centrene, mens direktionen har det overordnede embedsmandsansvar for ministeriets forretninger med departementschefen som formand for direktionen og øverste chef for alle områder. Direktionen er beslutningsforum for strategiske beslutninger af de overordnede rammer for ministeriets virksomhed, herunder HR og ressourcer.

Som en nyskabelse oprettes også et såkaldt koncernledelsesforum bestående af direktionen og centercheferne. Koncernledelsen varetager løbende ledelsesmæssig koordinering og styring af politikområderne under Udenrigsministeriets ressort. Koncernledelsen gennemfører også regelmæssige strategiske drøftelser, herunder et årligt strategiseminar, som bl.a. har til formål at bidrage til formulering af en årlig prioritetsplan for Udenrigsministeriets arbejde. Departementschefen er formand for koncernledelsen.

Reorganiseringen er først og fremmest møntet på hjemmetjenesten, mens udetjenesten ikke direkte påvirkes. Udetjenesten har allerede været igennem en større forandringsproces de senere år. Siden globaliseringsanalysen har Udenrigsministeriet således gradvist rykket ressourcer fra især Europa til Asien, og samtidig også styrket nogle af de politiske brændpunkter særligt i Mellemøsten.

Til gengæld skulle den nye struktur i hjemmetjenesten øge mulighederne for en tættere inddragelse af repræsentationerne ude i sagshåndtering og policyformulering, med bedre udnyttelse af den ressourcemæssige merværdi i udetjenesten.

Udenrigsministeriets nye struktur bryder på en række punkter med den struktur, som indførtes i 1991. På andre områder er der derimod tale om en fuldførelse af de intentioner og organisatoriske principper, som lå bag ændringerne i 1991. Reorganiseringen er således udtryk for såvel brud som kontinuitet.

\section{Tværgående organisationsprincip}

Det største brud med den gamle organisation ligger i det tværgående organisatoriske princip, hvor den hidtidige geografiske opdeling i en Nord- og en Sydgruppe erstattes af en tematisk og funktionel arbejdsdeling i den nye centerstruktur med en tværgående koncernledelse. Det geografiske princip, som blev indført med reorganiseringen i 1991, indebærer, at arbejdsdelingen indrettes efter de lande og regioner, der skal dækkes, frem for de funktioner, der skal varetages. Baggrunden for overgangen til et tematisk/ funktionelt organisationsprincip er først og fremmest de koordinationspro- 
blemer, som efterhånden var opstået i den gamle geografiske struktur.

Den geografiske opgavefordeling i Udenrigsministeriet er således bundet op på en stadig mere utidssvarende sondring mellem industrialiserede og ikke-industrialiserede lande. Det stikker i øjnene, at forholdet til Sydkorea håndteres i Sydgruppen, mens forholdet til Japan håndteres i Nordgruppen. Tilsvarende håndteres tre af de fire BRIClande i dag i Sydgruppen.

Landekontorerne i Nord og Syd har i dag mere tilfælles i form af problemstillinger, arbejdsformer, output og interessenter, end de har med tematiske kontorer i deres egne grupper. Endelig er sikkerhedspolitikken forankret i Nordgruppen, mens hovedparten af de sikkerhedspolitiske udfordringer ligger i geografiske områder, som varetages af Sydgruppen.

Endvidere har den nuværende organisationsstruktur, som er præget af det geografiske organisationsprincip, medført en fragmenteret tilgang til nye emner såsom klima og energi, menneskerettigheder samt terror og stabiliseringsindsatser. Disse udfordringer kræver en koordineret opfølgning i Udenrigsministeriet, men håndteres i dag af mange forskellige enheder og på tværs af grupperne. At de nye emner omtales som tværgående, skyldes derfor ikke kun, at de er mere komplekse sammenlignet med ministeriets traditionelle opgaver, men også at den nuværende struktur ikke er tilpasset den ændrede opgavevaretagelse.

Den fragmenterede opgavevaretagelse stiller desuden unødvendigt store krav til chefer og medarbejdere for at sikre afstemning, koordination og reel sammenhæng $i$ indsatserne.

Med den nye centerstruktur etableres en mere tidssvarende opgavefordeling, således at der skabes en klarere strukturel forankring af særligt de nye emner. Centrene er således enten udtryk for et tema som $\mathrm{x}$ global sikkerhed, eller en funktion som $\mathrm{fx}$ juridisk tjeneste. Der er derfor ikke tale om en tilbagevenden til de rene funktionelle departementer, som kendetegnede ministeriet i tiden før 1991, eller den geografiske opdeling i tiden herefter.

Selvom det geografiske princip havde forrang, var strukturen fra 1991 reelt udtryk for en kombination af organisationsprincipper. Det kom bl.a. til udtryk i bevarelsen af funktionelle enheder som juridisk tjeneste og bistandsfaglig tjeneste. I de følgende år skete desuden en gradvis styrkelse af organisationens funktionelle elementer med etableringen af Danmarks Eksportråd i 2000 samt selvstændige søjler for Public Diplomacy og Borgerservice i 2006.

Tilsvarende vil også den ny struktur være en blanding af organisationsprincipper. Bl.a. er det geogra- 
fiske princip bevaret i form af to regionale centre. Herved fastholdes den integrerede tilgang, hvor landekontorerne er hovedansvarlige for såvel de politiske relationer som bistandssamarbejdet i de forskellige lande. Princippet om opdeling efter forum, dvs. om der er tale om et bilateralt eller et multilateralt spørgsmål, genfinde Center for Globale Udfordringer, som samler ministeriets multilaterale indsatser.

Med indførelsen af det geografiske organisationsprincip i 1991 kom det danske udenrigsministerium til at skille sig ud fra de lande, som vi normalt sammenligner os med. Indførelsen af den nye centerstruktur bringer imidlertid Udenrigsministeriet tilbage på linje med de øvrige udenrigstjenester, som grundlæggende har fastholdt en tematisk/funktionel organisering.

Ligheden er særlig stor, når der sammenlignes med den britiske udenrigstjeneste, som i dag er organiseret i en række funktionelle og tematiske direktorater, som følger ministeriets strategiske målsætninger. Der er dog den afgørende forskel, at det geografiske element i den britiske udenrigstjeneste er helt underordnet de tematiske enheder, mens landekontorerne i det danske udenrigsministerium samles i to selvstændige centre.

På det punkt minder den nye struktur mere om den svenske udenrigstjeneste, hvor der også findes en selvstændig regional blok.

\section{Den vertikale struktur}

Den vertikale struktur udtrykker måden, hvorpå en organisation designer sit hierarki og skaber over/ underordnelsesforhold, som forbinder organisationens chefer og enheder. Et vigtigt formål med indførelsen af den nye centerstruktur er at delegere beslutningskompetence i organisationen til lavest mulige niveau.

Interessant nok forsøgte man også under reorganiseringen i 1991 at afkorte hierarkiet, som man vurderede var blevet for stejlt. Det kan diskuteres, om der siden 1991 gradvist er sket en glidning tilbage mod et stejlere hierarki i Udenrigsministeriet. Der er dog intet som tyder på, at Udenrigsministeriet har flere hierarkiske lag end tilsvarende organisationer af samme størrelse.

Derimod har der været en oplevelse af, at sagsgangene undertiden er for tunge og bureaukratiske. Det skyldes dog næppe antallet af ledelseslag i sig selv, men skal nærmere findes $i$ ansvarsfordelingen og sammenhængen mellem og på tværs af de forskellige ledelseslag i organisationen.

Med den nye centerstruktur er det intentionen, at faglige spørgsmål, som alene vedrører et enkelt centers ansvarsområde, også bør afgøres der, således at sagsgangene i ministeriet gøres mere smidige. Beslutningskompetencen skal med andre ord ligge på det lavest mulige 
niveau i organisationen. I udgangspunktet bør derfor kun sager af væsentligt omfang, strategisk betydning, er nydannende, eller har tværgående karakter forelægges den $\varnothing v e r s t e$ ledelse. Som nævnt ovenfor er det ikke vurderingen, at det er selve antallet af ledelseslag, der udgør et problem. Derfor er antallet heller ikke blevet reduceret i den nye centerstruktur. Derimod har ledelseslaget mellem kontorchefer og direktion fået et mere entydigt ansvar i form af centerchefsrollen. Herved skabes også forudsætningerne for, at beslutningerne rent faktisk kan færdiggøres på centerniveauet, frem for at blive sendt videre op i hierarkiet.

Der lægges således op til en decentralisering af beslutningskompetencen i de løbende daglige sager. Departementschefen er overordnet de øvrige medlemmer af direktionen og skal sikre, at den øverste ledelse på en række områder træffer de strategiske beslutninger i fællesskab; men ikke i løbende sager.

Den vertikale struktur i den nye organisation bryder således på afgørende områder med den gamle organisation. Organisatorisk kommer Udenrigsministeriet dermed på linje med strukturen i andre store ministerier som Økonomi- og Erhvervsministeriet, dog med de forskelle der ligger $i$ at have to politiske chefer og et meget heterogent og dynamisk ansvarsområde. Der er dog tale om kontinuitet i den for- stand, at ambitionen om en fladere struktur ligger i direkte forlængelse af principperne for reorganiseringen i 1991.

\section{Personalepolitik og støttefunktioner}

Enhver organisation, som er organiseret i faglige hovedgrupper, må vælge, hvordan den vil understøtte disse med støttefunktioner, herunder HR, regnskaber, kommunikation og udviklingsopgaver.

Støttefunktionerne kan enten centraliseres, således at de samme støttefunktioner servicerer alle organisationens hovedgrupper, eller der kan skabes støttefunktioner i hver enkelt hovedgruppe.

Målet med reorganiseringen i 1991 var bl.a. at skabe en enhedstjeneste, hvor medarbejderne gjorde karriere på tværs af hovedgrupperne, og hvor kulturen tilsagde, at man tilhørte én og samme organisation, uanset om man arbejdede med handel eller udviklingsbistand, eller om man sad på Asiatisk Plads eller en repræsentation i udlandet.

Det lykkedes dog aldrig at realisere ambitionen om en fuldt udfoldet enhedstjeneste, hvilket bl.a. skyldtes, at en lang række støttefunktioner, herunder især på personaleområdet, de facto var lagt ud til de enkelte grupper i en uformel struktur. Konsekvensen var, at særligt Nordgruppen, Sydgruppen og Danmarks Eksportråd i praksis opbyggede egne personalepolitikker, 
der udfyldte en række basale HRfunktioner, men også styrkede silotænkningen på bekostning af koncerntilgangen. Hertil kom problemer med duplikation af en række driftsopgaver.

Med overgangen til centerstrukturen lægges op til en nyorientering af ministeriets tilgang til human ressources. Det er vurderingen, at hvis Udenrigsministeriets skal have en fuldt udfoldet enhedstjeneste, er det ud over en tværgående koncernledelse nødvendigt at udvikle en stærk HR-funktion på koncernniveau.

Det betyder, at personaleansvaret fjernes fra de nuværende grupper og centraliseres i det nye Center for Koncern-HR og Ressourcer. Samtidig lægges op til rekruttering af eksterne HR-specialister, herunder en ekstern HR-chef, som skal medvirke til en øget professionalisering af HR-arbejdet i ministeriet.

Der er dog ikke kun tale om en centralisering af HR-arbejdet, idet den nye centrale HR-funktion vil skulle indgå i en tæt dialog med linjecheferne i hjemmetjenesten og repræsentationschefer i udetjenesten, som har det primære personaleansvar i organisationen. Forskellen mellem den gamle og den nye organisation er derfor primært, at mellemleddet i form af selvstændige og uformelle støttefunktioner i grupperne nedlægges. Reorganiseringen på HR-området er derfor udtryk for centralisering og decentralisering på samme tid.
Foruden en opprioritering af arbejdet med HR indebærer reorganiseringen også, at Udenrigsministeriets driftsopgaver, herunder IT og arkivfunktion, samles i et selvstændigt center. En sådan synliggørelse giver mulighed for synergiskabelse og effektiviseringer.

Også her er det tanken, at ministeriet i højere grad end tidligere skal anvende eksterne specialister. Den centraliserede økonomistyring fastholdes og udvides med en gradvis samling af de administrative opgaver for repræsentationerne i udlandet i regionale centre.

Sammenfattende er den nye organisering af HR-området udtryk for et forsøg på at fuldføre ambitionen om fuldt udfoldet enhedstjeneste, som blev fremsat i forbindelse med reorganiseringen i 1991.

\section{Strategi og ressourcer}

Globaliseringens mange nye opgaver har udfordret Udenrigsministeriets evne til at prioritere mellem opgaver og ressourcer, idet de nye opgaver kun i begrænset omfang har været fulgt op med ekstra ressourcer. Samtidig er det netop vanskelighederne ved at prioritere, som har medført, at ministeriet ikke altid har kunnet give den fornødne vægt og fokus til de nye indsatsområder, som var en følge af Globaliseringsanalysens anbefalinger.

Et vigtigt formål med reorganiseringen er derfor at styrke ledelsens 
evne til at prioritere mellem opgaver og ressourcer. Samtidig er der behov for større fleksibilitet, så medarbejdere og ressourcer lettere kan flyttes på tværs af kontorer og centre og mellem ude- og hjemmetjenesten i overensstemmelse med de udviklings- og udenrigspolitiske prioriteringer i regeringens politik.

Der lægges derfor op til, at der fremover årligt udarbejdes en koncernfælles prioritetsplan, som kan danne udgangspunkt for ministeriets prioritering af opgaver og ressourcer.

Prioritetsplanen er samtidig udtryk for en øget fokus på koncernfælles policyplanlægning i Udenrigsministeriet. Dette element understøttes også af den nye strategi- og planlægningsenhed, som netop får ansvaret for prioritetsplanen, og desuden har til formål at forudse og analysere de nye udviklingstræk samt igangsætte tværgående og langsigtet policyplanlægning.

Enheden er etableret i erkendelse af, at selvom der i ministeriet findes en række kritiske kompetencer både ude og hjemme - så koordineres og anvendes den eksisterende viden ikke systematisk, hvorved ministeriet forpasser mulighederne for at skabe en mere sammenhængende policyformulering.

Såvel prioritetsplanen som strategi- og planlægningsenheden er udtryk for en centralisering af ressourcestyringen og strategiprocesserne i Udenrigsministeriet på ledelses- niveau. Hermed styrkes den politiske forankring af alle ministeriets aktiviteter både på ledelses- og centerniveau.

Samtidig fortsættes tendensen mod større og stærkere stabsfunktioner, som netop har til formål at sikre den koncernfælles koordination og planlægning. Foruden etableringen af strategi- og planlægningsenheden styrkes således også direktionssekretariats tværgående rolle i den nye struktur.

Disse udviklingstræk er dog på ingen måde særegne for Udenrigsministeriet, men følger en generel tendens i centraladministrationen. Eksempelvis har Økonomi- og Erhvervsministeriet investeret massivt i udviklingen af koncernprojekter og årlige prioriteringsøvelser.

\section{Sammenfatning og perspektivering}

Kodeordene for Udenrigsministeriets nye organisation er enhedstjeneste og tværgående koncerntilgang. Helt overordnet er målsætningerne at mindske koordinationsproblemerne og styrke samtænkningen, afkorte hierarkiet og effektivisere sagsgangene, sikre større organisatorisk fleksibilitet samt personalepolitisk styrke princippet om en enhedstjeneste.

Målsætningerne søges opnået med andre midler end i 1991. Det ses bl.a. i valget af organisatorisk grundprincip, hvor den geografiske opdeling afskaffes til fordel for en 
tematisk og funktionel arbejdsdeling, og i tilgangen til ressourcestyring og indplacering af støttefunktioner, hvor der lægges op til en centralisering af ansvaret.

Kan den nye organisation indfri forventningerne, og hvad er udfordringerne på længere sigt?

En første udfordring bliver at sikre, at de nye centre ikke udvikler sig til nye siloer. I modsat fald er intet vundet ved overgangen fra seks grupper til elleve centre. Risikoen synes dog mindre end i den gamle struktur, hvor silotænkningen blev understøttet af, at grupperne rådede over selvstændige støttefunktioner, og at medarbejderne pga. størrelsen kunne gøre livslang karriere inden for den samme gruppe. Disse forhold er ikke til stede i den nye struktur.

En anden udfordring er, at koordinationsbehovet naturligt øges med overgangen fra seks grupper til elleve centre. Her skal koncernledelsen for alvor står sin prøve som tværgående koordinationsforum mellem centrene. Omvendt skal det understreges, at koordinationsbehovet i den nye organisation burde være mindre end i den gamle, idet opgavefordelingen er tilpasset, så de medarbejdere og enheder, som arbejdede med samme problemstillinger forskellige steder i den gamle struktur, nu samles inden for fælles organisatoriske rammer.

En tredje udfordring ligger i den vertikale struktur, hvor der lægges op til en decentralisering af den faglige beslutningskompetence til de enkelte centre. Hierarkier har det imidlertid med at genoprette sig selv, hvis ikke der gøres en aktiv indsats. Det bliver derfor interessant at se, om ambitionen kan realiseres, idet den nye struktur kun i begrænset omfang indeholder strukturelle værn mod en unødig detaljeret topstyring af organisationen. Således fastholdes en tematisk arbejdsdeling mellem direktionen og de elleve centre, men uden direkte ledelsesbånd, ligesom antallet af ledelseslag er uforandret.

En sidste udfordring ligger i spørgsmålet om stabsfunktioner, herunder personalehåndtering og prioritering af opgaver og ressourcer, hvor der lægges op til en centralisering af ansvaret.

Risikoen er her, at man fra et meget decentralt system svinger helt over i den anden grøft til et centralistisk system, hvor fx den koncernfælles HR-funktion mister følingen med de personalepolitiske behov i linjen og blandt medarbejderne, herunder de særlige faglige behov som knytter til fx rekruttering af økonomer, jurister, eksportmedarbejdere eller bistandsfaglige eksperter. En relateret problemstilling er, at den centraliserede HR-funktion kun vil kunne arbejde effektivt, hvis direktionen og centercheferne afstår fra utidig indblanding i særligt stillingsbesættelser. I modsat fald vil tilliden til den koncernfælles HR- 


\section{LARS BO MØLLER \& RASMUS ABILDGAARD KRISTENSEN}

funktion i begge tilfælde blive undergravet, hvorved der i værste fald gendannes uformelle og parallelle systemer. Ansættelsen af eksterne HR-specialister er dog et forsøg på at imødegå disse udfordringer.

Trods ovennæunte udfordringer er det imidlertid vurderingen, at der med reorganiseringen er skabt en tidssvarende organisatorisk ramme, som effektivt kan understøtte ministeriets strategiske målsætninger.

Reorganiseringen skulle gerne skabe et ministerium, som er endnu mere fleksibelt og proaktivt $\mathrm{i}$ håndteringen af såvel nye udfordringer som traditionelle kerneopgaver. Et ministerium som endnu bedre formår at udnytte de synergier, der ligger i enhedstjenesten, til gavn for danske og udenlandske samarbejdspartnere. Og et ministerium som får det bedste ud af sine menneskelige ressourcer, og som prioriterer effektivt mellem opgaver og ressourcer.

Indtil 1. juni 2009 er omstrukture- ringen teori. Prøven skal stå i den praktiske gennemførelse i realtid. Organisationsændringerne vil kun have begrænset effekt, hvis ikke organisationskulturen følger med.

Den største udfordring for Udenrigsministeriet de kommende år bliver derfor at fremme en fælles virksomhedskultur, som understøtter ministeriets evne til at agere over for de nye udfordringer, som globaliseringen skaber, og levere de konkrete resultater, som ministrene, regeringen og det danske samfund med rette kan stille krav om.

Kun på den måde, kan der for alvor skabes et moderne, fremtidssikret og globaliseringsparat ministerium.

Lars Bo Møller er kontorchef $i$ Udenrigsministeriet, hvor han har varet projektleder for implementeringen. Fuldmegtig Rasmus Abildgaard Kristensen har veret primus motor $i$ arbejdet og sekretar for Globaliseringsagenterne. 